\title{
Kształtowanie bezpieczeństwa i higieny pracy w przedsiębiorstwie a cechy kultury organizacyjnej
}

\author{
Anna Cierniak-Emerych \\ Katedra Pracy i Stosunków Przemysłowych, \\ Uniwersytet Ekonomiczny we Wrocławiu
}

\begin{abstract}
W opracowaniu przybliżono relacje zachodzące pomiędzy podnoszeniem poziomu bezpieczeństwa i higieny pracy (bhp) w przedsiębiorstwie a kształtowaniem kultury organizacyjnej, w tym kultury bhp. Odnosząc się do wyników badań empirycznych zidentyfikowano podejście do zagadnienia bezpieczeństwa i higieny pracy w przedsiębiorstwach zlokalizowanych na ternie Dolnego Śląska. Szczególną uwagę zwrócono przy tym na cechy kultury organizacyjnej ujawnione w objętych badaniami przedsiębiorstwach, rozpatrując je w kontekście kształtowania kultury bhp.
\end{abstract}

Słowa kluczowe: kultura organizacyjna, kultura bhp, bezpieczeństwo i higiena pracy, poziom bhp, warunki pracy.

\section{Wstęp}

Zmienność rzeczywistości gospodarczej, z którą mamy współcześnie do czynienia utrwala wysoką rangę problematyki dotyczącej człowieka i jego pracy, stając się ważną przesłanką do weryfikowania działań podejmowanych w związku z kształtowaniem potencjału ludzkiego przedsiębiorstwa. W istocie odbywa się to poprzez realizację określonych zadań w ramach takich obszarów, jak m.in. miejsca pracy, funkcja personalna, czy też warunki pracy.

Nawiązując w sposób szczególny do ostatniego z wymienionych wyżej obszarów, tj. warunków pracy ${ }^{1}$, warto zaznaczyć, iż odpowiednie - adekwatne

1 W literaturze przedmiotu warunki pracy odnosi się do materialnych oraz niematerialnych elementów przedsiębiorstwa związanych z rodzajem i charakterem wykonywanej pracy. Za 
do potrzeb i możliwości osób świadczących pracę, jak i do okoliczności funkcjonowania przedsiębiorstwa - budowanie tych warunków sprzyja osiąganiu wzrostu zadowolenia z wykonywanej pracy, a w konsekwencji także i doskonaleniu rezultatów szeroko rozumianego gospodarowania w przedsiębiorstwie. Człowiek może bowiem wykonywać pracę w trudnych warunkach, ale pracować produktywnie, zachowując dobre zdrowie jedynie w otoczeniu odpowiadającym jego fizycznym oraz psychicznym i społecznym potrzebom oraz możliwościom² ${ }^{2}$.

Dla osób podejmujących współcześnie pracę istotnym - obok wysokości i struktury dochodu uzyskanego z tytułu realizacji pracy - staje się także a niekiedy nawet przede wszystkim, poczucie bezpieczeństwa pracy. Chodzi przy tym zarówno o bezpieczeństwo, rozumiane jako pewność posiadania pracy, jak również dbałość o zapewnienie określonego stanu bezpieczeństwa i higieny pracy w przedsiębiorstwie (bhp), czyli zabezpieczenie pracowników przed zagrożeniami dla ich życia i zdrowia, występującymi podczas pracy a znajdującymi źródło w stanie materialnych i niematerialnych składowych warunków pracy.

Zagadnienie doskonalenia warunków pracy a w rezultacie podnoszenia poziomu bezpieczeństwa i higieny pracy w przedsiębiorstwach funkcjonujących w krajach Unii Europejskiej, stanowi jedno z ważniejszych zadań sformułowanych w ramach wspólnotowej polityki społecznej i zatrudnienia. Świadczy o tym szereg aktów prawa wspólnotowego nawiązujących do omawianych tutaj zagadnień, wśród których uwagę zwraca zbiór dyrektyw wspólnotowych. W szczególności znajduje to wyraz w tzw. dyrektywie ramowej 89/391/ WE o wprowadzaniu środków w celu zwiększenia bezpieczeństwa i poprawy zdrowia pracowników podczas pracy oraz związanych z nią tzw. dyrektywach szczegółowych, stanowiących swego rodzaju uzupełnienie dyrektywy ramowej.

O randze omawianej problematyki, świadczy ponadto opracowana na lata 2007-2012 wspólnotowa strategia na rzecz bezpieczeństwa i higieny pracy. W strategii tej za szczególnie ważne uznano zmniejszenie ogólnego wskaźnika wypadków przy pracy o $25 \%$. Ma to następować m.in. poprzez udoskonalanie obowiązujących regulacji z zakresu prawa, skuteczniejsze wdrażanie istniejących zapisów prawa dotyczących bhp, monitorowanie stanu bhp, jak i prowadzenie badań naukowych w omawianym zakresie. Za ważne uznaje się również

elementy te uznaje się w szczególności materialne warunki pracy, czas pracy, działalność socjalno-bytową oraz stosunki pracy Por. np. A. Pocztowski, Zarządzanie zasobami ludzkimi. Zarys problematyki i metod, Wyd. Antykwa, Kraków 1998, s. 261.

2 A. Cierniak-Emerych, Warunki pracy - ich składowe oraz pożadane rezultaty kształtowania w: Potencjat pracy przedsiębiorstwa, red. M. Gableta, Wyd. AE Wrocław, Wrocław 2006, s. 117. 
traktowanie dbałości o stan bhp jako inwestycji związanej z podnoszeniem konkurencyjności przedsiębiorstwa a nie bariery ograniczającej tę konkurencyjność 3 .

Nawiązując do tak sformułowanych zaleceń, w Rezolucji Parlamentu Europejskiego z dnia 15 stycznia 2008 r. w sprawie wspólnotowej strategii na rzecz bezpieczeństwa i higieny pracy na lata 2007-2012 (2007/2146(INI)), w sposób istotny zwraca się przy tym uwagę m.in. na fakt, iż wskazane wyżej działania w zakresie bhp muszą stanowić część kultury przedsiębiorczości, kultury organizacyjnej przedsiębiorstwa i związanej z nią kultury bhp. Przyjmuje się bowiem, że konsekwentnie wprowadzana kultura bhp, a w istocie odpowiednio ukształtowany system norm, wartości, sposobów postępowania w zakresie bezpieczeństwa i higieny pracy, może przyczynić się do niebiurokratycznego wdrażania procedur bhp, a tym samym do podnoszenia poziomu bezpieczeństwa pracy ${ }^{4}$.

Mając to na uwadze celem opracowania stało się ukazanie związków zachodzących pomiędzy podnoszeniem poziomu bezpieczeństwa i higieny pracy w przedsiębiorstwie a kształtowaniem kultury organizacyjnej. Odnosząc się do wyników badań empirycznych ${ }^{5}$ zidentyfikowano podejście do zagadnienia bezpieczeństwa i higieny pracy w przedsiębiorstwach zlokalizowanych na ternie Dolnego Śląska6. Szczególną uwagę zwrócono przy tym na cechy kultury organizacyjnej ujawnione $\mathrm{w}$ objętych badaniami przedsiębiorstwach, rozpatrując je w kontekście kształtowania kultury bhp oraz osiągania określonego poziomu bhp.

Tłem dla realizacji tak sformułowanego celu stała się prezentacja podstaw budowania kultury bhp w przedsiębiorstwie rozpatrywanej jako element jego kultury organizacyjnej a następnie prezentacja istoty oraz cech tzw. poziomów bezpieczeństwa i higieny pracy. Podjęto przy tym próbę ukazania relacji zachodzących pomiędzy „osiąganiem” kolejnych spośród tych poziomów a cechami kultury organizacyjnej.

3 Wspólnotowa strategia na rzecz podniesienia bezpieczeństwa i higieny pracy, http://eur-lex. europa.eu/LexUriServ/LexUriServ.do?uri=OJ:C:2009:041E:0014:0023:PL:PDF , [dostęp one-line 12.11.2012].

4 Ibidem.

5 Badania, o których mowa miały charakter badań pilotażowych. Przeprowadzono je w 32 przedsiębiorstwach w latach 2011-2012.

6 Szerszą charakterystykę objętych badaniami przedsiębiorstw zaprezentowano w punkcie 3 niniejszego opracowania. 


\section{Kształtowanie kultury bezpieczeństwa i higieny pracy w przedsiębiorstwie}

Kultura organizacyjna stanowi „społeczne spoiwo” przedsiębiorstwa, odzwierciedlając wspólny system znaczeń, tworząc tym samym podstawę komunikowania się i wzajemnego zrozumienia ${ }^{7}$. Równocześnie jest określa jako „...system wartości i norm zachowań oraz sposobów postępowania i myślenia, który został wykształcony i zaakceptowany przez pewien zespół ludzi i który powoduje wyraźne wyróżnienie tego zespołu od innych"8.

$\mathrm{Z}$ obowiązującego w danym przedsiębiorstwie systemu wartości wynika m.in. stosunek pracowników, ale i pracodawcy do9:

- pracy (dbałość o jakość realizowanych zadań, poziom zaangażowania w ich realizację, dbałość o warunki wykonywania pracy),

- autorytetów (lojalność, zaufanie, skłonność do wyrażania opinii),

- współdziałania (gotowość do pracy zespołowej, grupowej, gotowość do dzielenia się wiedzą, gotowość do uczestnictwa w procesach decyzyjnych). Kultura organizacyjna, w pewien sposób łącząc, zatem - poprzez wspólny i zaakceptowany system wartości - ludzi w przedsiębiorstwie, nie pozostaje bez wpływu na pożądane rezultaty jego działalności. Jeżeli więc kulturę organizacji charakteryzują określone cechy, może ona wspomagać realizację oczekiwanych wyników w poszczególnych obszarach funkcjonowania przedsiębiorstwa. Jak już stwierdzono wyżej, za jeden z tych obszarów uznaje się obszar warunków pracy i związaną z nim problematykę bezpieczeństwa i higieny pracy.

W literaturze przedmiotu coraz częściej określone znaczenie w procesie budowania odpowiednich warunków pracy nadaje się właśnie podejściu do kształtowania systemu norm, wartości, sposobów postępowania. Preferuje się przy tym ich ukierunkowanie na ochronę zdrowia i życia w miejscu pracy, brak akceptacji dla nieprzestrzegania wymogów prawa dotyczących stanu składowych warunków pracy, eliminowanie zagrożeń występujących na stanowiskach pracy oraz wypadków w pracy, poprawę stanu materialnych i niematerialnych elementów warunków pracy, podnoszenie poziomu świadomości zatrudnionych na temat bezpieczeństwa i higieny pracy (m.in. poprzez szkolenie w tym zakre-

7 Zob. M. Armstrong, Zarządzanie zasobami ludzkimi, Oficyna Ekonomiczna, Kraków 2005, s. $248-250$.

8 Organizacja i zarzqdzanie, red. J. Boroń, AE Poznań, Poznań1991, s. 199.

9 Por. M. Gableta, E. Karamalla, Pojęcie i rola kultury organizacyjnej w przedsiębiorstwie w: Potencjat pracy $w$ przedsiębiorstwie. Kształtowanie $i$ wykorzystanie, Wyd. AE Wrocław, Wrocław 1998, s. 48-49. 
sie) oraz ciągłą ocenę stanu tego bezpieczeństwa. Tak zarysowane ukierunkowanie systemu norm, wartości, sposobów postępowania w przedsiębiorstwie będąc wyrazem zbiorowej, ale i indywidualnej wrażliwości poszczególnych pracowników i pracodawcy dotyczącej budowania warunków pracy stanowi wyraz urealniania kultury bezpieczeństwa i higieny pracy, rozumianej jako element jego kultury organizacyjnej ${ }^{10}$. Warto w tym miejscu wskazać, iż w literaturze przedmiotu nie ma pełnej zgodności co do definiowania pojęcia kultura bezpieczeństwa i higieny pracy, co skutkuje prezentacją różnych podejść do jej rozumienia ${ }^{11}$.

Kulturę bhp należy traktować jako zmienną, której wartościami granicznymi są tzw. kultura bezwzględnego bezpieczeństwa, innymi słowy kultura „pożądana”, czyli sprzyjająca zapewnieniu możliwie optymalnego stanu bezpieczeństwa i higieny pracy w przedsiębiorstwie oraz kultura poszukiwania ryzyka (kultura „niepożądana”). Pomiędzy tak ujętymi wartościami granicznymi kultury bhp mamy do czynienia z tzw. kulturą mieszaną ${ }^{12}$.

Najważniejszą rolę w tworzeniu „pożądanej” kultury bhp, przypisuje się przede wszystkim pracodawcy. Przyjmuje się, iż powinien on w szczególności podejmować w tym zakresie takie działania, jak ${ }^{13}$ :

- ustalanie założeń polityki bezpieczeństwa i higieny pracy stanowiącej aspekt polityki personalnej,

- ustalanie oraz stosowanie w praktyce norm, zasad, procedur postępowania mających na celu identyfikację oraz minimalizowanie zagrożeń dla zdrowia i życia człowieka występujących w środowisku pracy,

- przyjęcie, iż postępowanie zgodnie z normami, zasadami bezpieczeństwa jest warunkiem zatrudnienia i pracy w przedsiębiorstwie,

- promowanie wśród wszystkich osób zatrudnionych, iż bezpieczeństwo jest wartością najcenniejszą a zarazem oddziałująca na realizację wszystkich celów przedsiębiorstwa,

10 Por. także A. Rakowska, M. Cichorzewska, Rola przywództwa w ksztattowaniu kultury bezpieczeństwa pracy, „Zeszyty Naukowe Wyższej Szkoły Bankowej we Wrocławiu” 2012, nr 30, s. $187-189$.

11 Chodzi tutaj o tzw. podejścia: manifestowanie, rdzeń oraz kompleksowe podejście do kultury. Szerzej zob. F.W. Guldenmund, (Mis)understanding Safety Culture and Its Relationship to Safety Management, "Risk Analysis" 2010, vol. 30, no. 10, s. 1467.

12 R. Studenski, Kultura bezpieczeństwa pracy w przedsiębiorstwie, „Bezpieczeństwo Pracy”, 2000 nr 9, s. 1-3.

13 Por. Z. Pawłowska, Kształtowanie kultury bezpieczeństwa i higieny pracy $w$ systemach zarzqdzania w: Nauka o pracy - bezpieczeństwo, higiena, ergonomia. Zarządzanie bezpieczeństwem $i$ higiena pracy, Tom 8, red. D. Koradecka, Wyd. CIOP, Warszawa 2000, s. 121-122. 
- rozwijanie - poza ujęte w obowiązującym ustawodawstwie wymagania troski o bezpieczeństwo własne i współpracowników,

- stymulowanie zaangażowania pracowników w proces doskonalenia warunków pracy wraz z promowaniem ich uczestnictwa w tym procesie,

- wyrażanie uznania dla osiągnięć indywidualnych i grupowych związanych z doskonaleniem warunków pracy, jak również stosowanie pozytywnych bodźców sprzyjających motywowaniu do ingerowania przez wszystkich zatrudnionych w sytuacji, kiedy postrzegane zachowania współpracowników są niebezpieczne,

- przygotowywanie i przekazywanie w sposób dostępny informacji o stanie warunków pracy i ich zgodności z obowiązującymi standardami,

- rzetelne szkolenie w zakresie bhp.

W praktyce - z różnych powodów - normy, zachowania zarówno pracodawców, jak i osób świadczących pracę, dotyczące tworzenia warunków pracy nie zawsze przybierają postać wskazanych wyżej a zarazem pożądanych z punktu widzenia kształtowania kultury bhp.

Mając to na uwadze zasadnym wydaje się podjęcie próby ukazania powiązań zachodzących pomiędzy preferowaniem w przedsiębiorstwie konkretnych norm, wartości, sposobów postępowania, a w rezultacie cech, czy też wymiarów kultury organizacyjnej w obszarze bhp a budowaniem określonego poziomu bezpieczeństwa i higieny pracy w przedsiębiorstwie.

\section{Poziomy bezpieczeństwa i higieny pracy a cechy kultury organizacyjnej}

Promowaniu - poprzez formułowanie określonych zapisów wytycznych prawa wspólnotowego, ale i polskiego - idei systematycznego kształtowania, a w tym doskonalenia bezpieczeństwa i higieny pracy w przedsiębiorstwach, towarzyszą podejmowane $\mathrm{w}$ literaturze przedmiotu próby wyróżniania tzw. poziomów bezpieczeństwa i higieny pracy wraz ze wskazaniem zmiennych charakteryzujących te poziomy. W tabeli 1 ukazano przykład postrzegania bezpieczeństwa i higieny pracy z uwzględnieniem czterech jego poziomów. Wśród zmiennych charakteryzujących każdy z wymienionych poziomów w kolumnie 5 ujęto cechy kultury organizacyjnej przedsiębiorstwa związane z problematyką (w obszarze) bezpieczeństwa i higieny pracy. 
Tabela 1 Poziomy bezpieczeństwa i higieny pracy

\begin{tabular}{|c|c|c|c|c|c|}
\hline $\begin{array}{l}\varepsilon \\
\frac{0}{N} \\
\end{array}$ & $\begin{array}{c}\text { Motywacja } \\
\text { do działania }\end{array}$ & $\begin{array}{l}\text { Rodzaj } \\
\text { działań }\end{array}$ & $\begin{array}{c}\text { Typowa } \\
\text { metoda oceny }\end{array}$ & $\begin{array}{l}\text { Cechy kultury organizacyjnej } \\
\text { w obszarze bhp }\end{array}$ & $\begin{array}{c}\text { Rezultaty } \\
\text { osiaggane } \\
\text { w obszarze bhp }\end{array}$ \\
\hline I & strach & bierne & $\begin{array}{l}\text { tylko inspekcje } \\
\text { instytucji } \\
\text { nadzorujących }\end{array}$ & $\begin{array}{l}\text { - brak określonej polityki bhp, } \\
\text { - ukierunkowanie na unikanie kar za } \\
\text { nieprzestrzeganie przepisów bhp, } \\
\text { - tylko podstawowe, obowiązkowe } \\
\text { szkolenia bhp, } \\
\text { - brak sprawnie funkcjonującej } \\
\text { komórki bhp, } \\
\text { - brak widocznych przejawów } \\
\text { stosowania środków ochrony } \\
\text { indywidualnej, } \\
\text { - tolerowanie niezgodności, } \\
\text { - koncentrowanie się na produkcji } \\
\text { i obniżaniu kosztów, } \\
\text { - niedobór wiedzy w zakresie bhp }\end{array}$ & $\begin{array}{l}\text { niepełna } \\
\text { zgodność, } \\
\text { wyniki gorsze } \\
\text { od średnich }\end{array}$ \\
\hline II & kara & reaktywne & $\begin{array}{l}\text { analiza } \\
\text { dokumentacji, } \\
\text { inspekcje }\end{array}$ & $\begin{array}{l}\text { - brak określonej polityki bhp, } \\
\text { - tylko podstawowe, obowiązkowe } \\
\text { szkolenia bhp, } \\
\text { - brak nawyków stosowania środków } \\
\text { ochrony indywidualnej, } \\
\text { - } \text { koncentrowanie się na produkcji } \\
\text { i obniżaniu kosztów, } \\
\text { - niedobór wiedzy w zakresie bhp } \\
\text { - } \text { orientacja na unikanie } \\
\text { niezgodności w dokumentacji bhp }\end{array}$ & $\begin{array}{l}\text { pełna } \\
\text { zgodność, } \\
\text { brak poprawy, } \\
\text { wyniki średnie }\end{array}$ \\
\hline III & nagroda & aktywne & $\begin{array}{l}\text { obserwacja } \\
\text { stanowisk } \\
\text { pracy, audity } \\
\text { systemu, }\end{array}$ & $\begin{array}{l}\text { - polityka bhp nie sprecyzowana } \\
\text { formalnie, } \\
\text { - instruowanie i wspieranie } \\
\text { pracowników w obszarze bhp, } \\
\text { - wzajemne zaufanie, } \\
\text { - orientacja zespołowa na } \\
\text { doskonalenie bhp, } \\
\text { - dążenie do wzrostu } \\
\text { bezpieczeństwa pracy, } \\
\text { - sprawny przepływ informacja nt. } \\
\text { stanu warunków pracy }\end{array}$ & $\begin{array}{l}\text { prawidłowe } \\
\text { zachowania, } \\
\text { wyniki lepsze } \\
\text { niż średnie }\end{array}$ \\
\hline IV & $\begin{array}{l}\text { motywacja } \\
\text { wewnętrzna }\end{array}$ & proaktywne & $\begin{array}{l}\text { przeglądy } \\
\text { i wywiady }\end{array}$ & $\begin{array}{l}\text { - określona formalnie polityka bhp, } \\
\text { - wzajemne zaufanie, } \\
\text { - poczucie wspólnoty, } \\
\text { - motywacja wewnętrzna do } \\
\text { doskonalenia stanu bhp, } \\
\text { - uczciwość, } \\
\text { - postulat „zero wypadków”, } \\
\text { - pasja, zaangażowanie w sprawy } \\
\text { doskonalenia stanu bhp }\end{array}$ & $\begin{array}{l}\text { ciągla } \\
\text { poprawa, } \\
\text { przywództwo, } \\
\text { wyniki } \\
\text { znakomite }\end{array}$ \\
\hline
\end{tabular}

Źródło: opracowanie własne przy wykorzystaniu: D. Podgórski, Wspótczesne koncepcje zarządzania bezpieczeństwem $i$ higiena pracy w: Nauka o pracy - bezpieczeństwo, higiena, ergonomia. Zarzq̨zanie bezpieczeństwem i higiena pracy, Tom 8, red. D. Koradecka, Wyd. CIOP, Warszawa 2000, s. 12-14; M.B. Weinstein, Total Quality Safety Management and Auditing, Boca Raton FL, CRC Press LLC 1997. 
Poziom I wyraża stan niepełnej zgodności warunków pracy z przyjętymi zwłaszcza w regulacjach prawnych standardami w zakresie bhp. Charakteryzuje on przedsiębiorstwa, w których nie przywiązuje się większej uwagi do tworzenia bezpiecznych i higienicznych warunków pracy. Dąży się w nich jedynie do unikania kar i grzywien za występujące niezgodności stanu tych warunków z wytycznymi przepisów prawa. W konsekwencji nie mobilizuje to do poprawy stanu bhp, a jedynie stanowi podstawę osiągania rezultatów określanych jako niepełna zgodność z przyjętymi standardami, w tym głównie z wytycznymi prawa. Preferowane w tych przedsiębiorstwach wartości w obszarze bhp cechuje zatem brak jasno sformułowanej polityki w zakresie bhp, tolerowanie niezgodności, ukierunkowanie jedynie na unikanie kar i grzywien nakładach przez organy nadzoru i kontroli (tab. 1). Tak ujęte wartości, sposoby postępowania można zatem określić, jako charakterystyczne dla kultury organizacyjnej zadaniowej, zachowawczej, ale i opartej na braku zaufania do pracownika.

Poziom II bezpieczeństwa i higieny pracy dotyczy przedsiębiorstw, w których motywacją do podejmowania działań staje się obawa przed karą. W tych przedsiębiorstwach jedną z cech kultury organizacyjnej staje się zatem unikanie niezgodności (tab. 1). Charakterystycznym sposobem postępowania staje się więc przede wszystkim dążenie do zapewnienia zgodności zapisów ujętych w odpowiednich - formułowanych na poziomie przedsiębiorstwa dokumentach - z adekwatnymi zapisami w regulacjach prawnych. Tak ujęta orientacja na unikanie niezgodności, w praktyce może jednak skutkować faktem, iż zgodność zapisów ujętych w dokumentach formalnych oraz przepisach prawa, nie stanowi w pełni odzwierciedlenia faktycznego stanu bhp w przedsiębiorstwie. W odniesieniu do II poziomu bezpieczeństwa i higieny pracy, jak się wydaje, możemy - podobnie jak dla poziomu I- mówić o kulturze organizacyjnej zachowawczej. Kulturę bhp można tutaj określić jako mieszaną, tj. z jednej strony zbliżona do „niepożądanej”, jednak dająca podstawę do osiągania rezultatów zgodności, ale bez możliwości obserwowania braku poprawy stanu bhp.

Analizując ujęte w tabeli 1 informacje można stwierdzić, iż w przedsiębiorstwach, dla których charakterystycznymi cechami ich kultury organizacyjnej staje się strach, unikanie niezgodności w obszarze bhp (I lub II poziom bhp) rezultaty dotyczące stanu bhp cechuje brak dążenia do doskonalenia warunków pracy, w tym do dostosowywania tych warunków do fizycznych, psychicznych i społecznych potrzeb pracowników. Poprawie stanu bhp sprzyja natomiast dopiero podejmowanie działań opartych na wzajemnym zrozumieniu potrzeb podnoszenia poziomu bhp. Ważną przesłanką trwałych, a przy tym pozytywnych zmian w zakresie bhp jest sytuacja, w której pracodawcy i pracownicy odczuwają wewnętrzną motywację do doskonalenia bhp, są zaangażowani 
w systematyczne ulepszanie warunków pracy, zwłaszcza poprzez aktywne uczestnictwo w tym ulepszaniu, poprzez co zatrudnieni mogą odczuwać poczucie wspólnoty w doskonaleniu warunków pracy (tab.1). Obdarza się ich przy tym zaufaniem, co sprzyja postrzeganiu ich oczekiwań dotyczących poprawy warunków pracy, nie w kategoriach dodatkowych „roszczeń” względem pracodawcy, ale impulsu do wzrostu zaangażowania w działania na rzecz realizacji celów przedsiębiorstwa. Ponadto, za istotną zmienną stanowiącą zaczyn do owych trwałych, pozytywnych przeobrażeń sprzyjających doskonaleniu warunków pracy należy uznać sformułowaną oraz przyjętą w przedsiębiorstwie politykę dotyczącą omawianego bezpieczeństwa. Znajduje to wyraz zwłaszcza na IV spośród omawianych poziomów bhp.

Dokonując pewnych podsumowań można stwierdzić, że kultura bezpieczeństwa i higieny pracy wyraża charakterystyczny dla przedsiębiorstwa stan świadomości zagrożeń, funkcjonujące formalne i nieformalne zasady postępowania w sytuacji zagrożeń, które powodują, iż w praktyce mamy do czynienia z określonym - specyficznym dla konkretnego przedsiębiorstwa - podejściem do bezpieczeństwa i higieny pracy ochrony zdrowia w procesie zarządzania przedsiębiorstwem ${ }^{14}$. Innymi słowy możemy mówić o bezpośredniej relacji pomiędzy określonymi cechami kultury bhp a poziomem bhp w organizacji. Kultura określana w literaturze mianem „niepożądanej” będzie specyficzna dla firm charakteryzujących się osiąganiem przede wszystkim pierwszego poziomu bhp. Z kolei z kulturą bezwzględnego bezpieczeństwa, czyli kulturą „pożądaną” będziemy mieć do czynienia w przedsiębiorstwach, dla których osiągalnym jest czwarty poziom bhp.

Na tym tle rodzi się pytanie o cechy kultury organizacyjnej w obszarze bezpieczeństwa i higieny pracy a zarazem poziom tego bezpieczeństwa i powiązania między nimi charakterystyczne dla przedsiębiorstw funkcjonujących w Polsce.

14 R. Studenski, Kultura bezpieczeństwa pracy..., op. cit. 


\section{Kształtowanie bezpieczeństwa i higieny pracy w przedsiębiorstwach funkcjonujących w Polsce - prezentacja wyników badań empirycznych}

Badaniami pilotażowymi ${ }^{15}$ dotyczącymi identyfikacji podejścia do kształtowania bezpiecznych i higienicznych warunków pracy wraz z określeniem cech kultury organizacyjnej w obszarze bhp, objęto 32 przedsiębiorstwa produkcyjne oraz usługowe zlokalizowane na terenie Dolnego Śląska oraz województw ościennych. W badaniach uczestniczyło 148 respondentów określanych tutaj jako pracownicy, w tym 109 pracowników zajmujących stanowiska o charakterze wykonawczym oraz 39 respondentów pełniących funkcje kierowników najniższego oraz średniego szczebla zarządzania. Posłużono się kwestionariuszem pytań skategoryzowanych a otrzymane wyniki uszczegółowiono w trakcie przeprowadzenia „luźnych” wywiadów. Ponadto, w każdym z objętych badaniami przedsiębiorstw przeprowadzono wywiady z przedstawicielami właścicieli/lub najwyższego szczebla kierowania.

$\mathrm{Na}$ podstawie przeprowadzonych badań empirycznych, w tym głównie wywiadów z pracownikami, ale i z kadrą kierowniczą najwyższego szczebla zarządzania ujawniono, że w ponad połowie przebadanych przedsiębiorstw dominują dość zachowawcze postawy związane z kształtowaniem bezpieczeństwa i higieny pracy. Nawiązują one przede wszystkim do cech charakteryzujących podmioty gospodarcze, które można przyporządkować głównie do II spośród omówionych wyżej poziomów bhp. Niemniej wśród objętych badaniami znalazły się także podmioty, w których ujawniono symptomy charakterystyczne dla I poziomu bhp.

Odnosząc się do tych ostatnich - nawiązując do cech poziomów bhp ujętych w tab. 1- stwierdzono, że w blisko $18 \%$ objętych badaniami przedsiębiorstw motywacją do podejmowania określonych działań w obszarze bhp jest głównie strach, a podejmowane działania w obszarze warunków pracy ukierunkowuje się na unikanie kar za nieprzestrzeganie przepisów bhp. Charakterystycznym staje

15 Badaniami objęto trzydzieści przedsiębiorstw o profilu produkcyjnym (przemysł spożywczy, chemiczny, farmaceutyczny, meblarski oraz produkcja odzieży), a także jednostki usługowe. Wśród przeanalizowanych podmiotów dominowały funkcjonujące na terenie Dolnego Śląska. Najmniejsze z badanych przedsiębiorstw to przedsiębiorstwo jednoosobowe wytwarzające konfekcję damską i męską, zatrudniające 3 pracowników, natomiast największe - spółka akcyjna licząca ponad 900 zatrudnionych (przemysł chemiczny). Badania przeprowadzono w latach 2011-2012. 
się przy tym tolerowanie takich niezgodności w obszarze warunków pracy, jak przypadki niepełnego dostawania oświetlenia sztucznego, wentylacji pomieszczeń pracy, czy poziomu hałasu - do wymogów prawnych. Zaobserwowano także błędy w konserwacji urządzeń wentylacyjnych, brak widocznych przejawów stosowania środków ochrony indywidualnej. Ponadto, w pojedynczych przypadkach odnotowano niewłaściwy stan techniczny obiektów i pomieszczeń pracy oraz pomieszczeń socjalnych i sanitarnych; niewłaściwą eksploatację instalacji elektrycznych (uszkodzenia izolacji przewodów i obudowy urządzeń), złą organizację stanowisk pracy, w tym głównie zagęszczenie maszyn. Charakterystycznym dla $31 \%$ objętych badaniami przedsiębiorstw jest także brak przeprowadzonej oceny ryzyka zawodowego dla poszczególnych stanowisk pracy, co łączy się z niedopełnieniem wymogów prawnych nakazujących dokonywanie takiej oceny.

Kolejnym, stwierdzonym, w dziewięciu jednostkach (28\% objętych badaniami przedsiębiorstw), niepokojącym zjawiskiem jest brak, bądź nieprawidłowe działanie służb bhp., jak również nie spełnianie przez pracowników komórek bhp, wymogów formalnych dotyczących ich kwalifikacji.

Jak stwierdzono wyżej w większości objętych badaniami przedsiębiorstw (64\%) ujawniono symptomy pozwalające stwierdzić, iż w przedsiębiorstwach tych mamy do czynienia z „osiąganiem” II poziomu bhp. Świadczą o tym zarówno analizy dokonane z uwzględnieniem takich kryteriów, jak rodzaj działań w zakresie bhp, osiągane rezultaty, ale i interesujące nas w sposób szczególny ujawnione cechy kultury organizacyjnej, którą w tych podmiotach można określić mianem raczej „niepożądanej”.

Odnosząc się do cech poziomów bhp zestawionych w tabeli 1 stwierdzono, iż w przedsiębiorstwach tych wciąż brakuje przekonania o potrzebie systematycznego doskonalenia stanu bhp, podejmowane w tym zakresie działania mają charakter raczej akcyjny, sprzyjający uzyskiwaniu wyników średnich. Przedsiębiorstwa te - nawiązując do cech kultury organizacyjnej charakterystycznych dla II poziomu bhp - charakteryzuje głównie brak zdefiniowanej polityki w zakresie bhp, orientacja na unikanie niezgodności w dokumentacji. Ponadto można tutaj dostrzec działania ukierunkowane na koncentrowanie się głównie na produkcji i obniżaniu kosztów, a w niektórych przypadkach niedobór wiedzy w zakresie bhp.

W siedemnastu przedsiębiorstwach (53\% objętych badaniami) wiek części spośród stosowanych maszyn, urządzeń stanowi podstawę do stwierdzenia, że nie są one dostosowane do bieżących potrzeb wynikających z rozwiązań stosowanych w tym zakresie przez jednostki konkurencyjne, jak również do wymogów bhp. Chodzi np. o sytuacje, w których miał miejsce brak koniecznych 
osłon do tzw. części ruchomych maszyn. Dotyczy to przede wszystkim przedsiębiorstw produkujących odzież - jedenaście jednostek (34\% objętych badaniami), trzech meblarskich (ok. 9\% objętych badaniami), oraz trzech spożywczych (ok. 9\% objętych badaniami). Niedomogi parku maszynowego, w badanej grupie, są odczuwalne szczególnie dotkliwie w przedsiębiorstwach produkujących odzież. Zwłaszcza tam stwierdzono wystąpienie wypadków przy pracy, takich jak poparzenie gorącą parą przy prasowaniu, skaleczenie przy cięciu materiału itp. Warto przy tym wskazać, iż jednostki zajmujące się produkcją odzieży to głównie przedsiębiorstwa małe zatrudniające od 3-25 pracowników. Są to głównie przedsiębiorstwa zorientowane w większym zakresie na unikanie niezgodności w dokumentacji bhp niż - co powinno budzić niepokój - na poprawę stanu warunków pracy.

Potwierdzeniem tego mogą być także pewne nieprawidłowości zidentyfikowane $\mathrm{w}$ obszarze pozostałych składników materialnych warunków pracy, tj.: hałasu, oświetlenia, zapylenia. Przy czym zakres tych nieprawidłowości jest zróżnicowany. $\mathrm{Z}$ wywiadów przeprowadzonych z kadrą kierowniczą wynika, iż ma ona świadomość istnienia tych nieprawidłowości, ale w przeważającej liczbie przypadków brak środków finansowych uniemożliwia przeciwdziałanie tym zjawiskom. Przedstawiciele kierownictwa podkreślają, że „starają się” wypełniać w tym zakresie normy prawne. Tym niemniej mają świadomość, iż parametry hałasu, oświetlenia znajdują się na górnej granicy dopuszczalnych norm.

W omawianej grupie przedsiębiorstw ( $22 \%$ objętych badaniami), tj. charakteryzujących się "osiąganiem” II poziomu bhp zaobserwowano także sytuacje nieprzestrzegania norm czasu pracy, liczby godzin nadliczbowych, terminów urlopów itp. W szczególności zbytnie „obciążanie” pracowników sfery produkcyjnej nadmierną liczbą godzin nadliczbowych może wpływać niekorzystnie na stan ich zdrowia, a w rezultacie na efekty pracy. Warto przy tym dodać, iż analiza udostępnionej dokumentacji dotyczącej czasu pracy nie wykazuje nieprawidłowości związanych z nieprzestrzeganiem wytycznych prawa pracy. Można więc tutaj mówić o pewnych przejawach kultury organizacyjnej ukierunkowanej na unikanie niezgodności w dokumentacji charakterystycznych dla II poziomu bhp (zob. tab.1).

Na tym tle warto podkreślić, że wśród objętych badaniami przedsiębiorstw znalazły się również takie jednostki, w których rozpoznano cechy „pożądanej" kultury bhp, czyli kultury bezwzględnego bezpieczeństwa. Chodzi przede wszystkim o jedno spośród analizowanych przedsiębiorstw, w którym zidentyfikowano działania charakterystyczne dla III, a w niektórych aspektach nawet (jak np. kwestia określenia sformalizowanej polityki bhp, audyty menedżerskie 
w zakresie bhp, preferowanie wzajemnego zaufania itp.) dla IV poziomu bezpieczeństwa i higieny pracy.

W przedsiębiorstwie tym dąży się do osiągania możliwie najlepszych rezultatów w obszarze bhp. Pracownicy są pozytywnie, także finansowo, motywowani do aktywnego włączania się w działania mające na celu sprzyjać poprawie bezpieczeństwa i higieny pracy. Sprawnie funkcjonuje komórka bhp, jak również działa komisja bhp, która współpracuje z przedstawicielami służb bhp oraz z kierownictwem naczelnym. Określone zadania realizuje w omawianym zakresie także społeczny inspektor pracy, jak i przedstawiciele rady pracowników oraz związków zawodowych.

W sposób systematyczny dokonuje się przeglądów stanu bhp, także na podstawie sugestii zgłaszanych przez pojedynczych pracowników, którzy dodatkowo na bieżąco - z wykorzystaniem m.in. wewnętrznej poczty elektronicznej - informowani są o stanie warunków pracy. Dzięki pozytywnemu nastawieniu zarówno kierownictwa naczelnego szczebla, jak i większości pracowników na przestrzeni ostatnich dwóch, wyeliminowano ujawnione zagrożenia występujące w środowisku pracy, dzięki czemu znacznie ograniczono występowanie sytuacji potencjalnie wypadkowych oraz wypadkowych. W przedsiębiorstwie tym od blisko dwóch lat nie stwierdzono wypadku w pracy.

Szczególnie sprzyjające takim działaniom okazało się promowanie w omawianym przedsiębiorstwie określonych cech kultury organizacyjnej, czyli norm, wartości, sposobów postępowania opartych na wzajemnym zaufaniu, zaangażowaniu, orientacji zespołowej na doskonalenie bhp, a w szczególności promowaniu i realizacji w sposób ciągły szkoleń a szerzej edukacji w zakresie bhp, co można uznać za specyficzny - na tle innych spośród badanych przedsiębiorstw - wyznacznik, cechę ich kultury bhp.

Za ważny należy także uznać fakt, iż - co, jak już stwierdzono wyżej także stanowi jeden z wyznaczników „pożądanej” kultury bhp - w sposób sformalizowany opracowano założenia polityki bhp. Znalazły się wśród nich takie kwestie, jak: budowanie wśród pracowników świadomości i zaangażowania w sprawy bhp, ciągłe monitorowanie i doskonalenie działań w sferze bezpieczeństwa pracy, przestrzeganie najwyższych standardów bhp określonych przepisami prawa, ale i rozwijanie troski o bezpieczeństwo własne oraz współpracowników, wykraczając poza obowiązujące w ustawodawstwie wymagania.

Zaprezentowane rozważania - chociaż trudno na ich podstawie formułować wnioski o charakterze ogólnym m.in. z uwagi na pilotażowy charakter przeprowadzonych badań, jak również brak losowego doboru objętych badaniami przedsiębiorstw - a zwłaszcza przykład przedsiębiorstwa, w którym możemy mówić o ujawnieniu cech „pożądanej” kultury organizacyjnej, niejako potwier- 
dzają prezentowane w literaturze przedmiotu poglądy, iż „...wysoka kultura bezpieczeństwa charakteryzuje organizacje o wysokim poziomie bezpieczeństwa" 16 .

Mając na uwadze powyższe słusznym wydaje się stwierdzenie, iż przedstawione treści z pewności nie wyczerpują podjętej tutaj problematyki, ale skłaniają do prowadzenia dalszych, pogłębionych badań. W tym kontekście warto m.in. podjąć próbę zidentyfikowania czynników oddziałujących na kształtowanie określonych cech kultury bhp. Budowanie kultury bhp jest bowiem procesem złożonym i długotrwałym, na który oddziałuje wiele czynników wewnętrznych i zewnętrznych względem organizacji, co - jak starano się tutaj dowieść - ma swoje konsekwencje dla osiągania określonego poziomu bezpieczeństwa i higieny pracy.

\section{Podsumowanie}

Współczesne przedsiębiorstwa stają przed wyzwaniem stosowania różnorodnych narzędzi, sposobów, czy metod sprzyjających podnoszeniu poziomu bhp. Jak wykazano, w części objętych badaniami przedsiębiorstw w dalszym ciągu nie docenia się znaczenia problematyki bezpieczeństwa i higieny pracy rozpatrywanej zarówno w kontekście ochrony zdrowia i życia pracowników, jak również w kontekście osiągania określonych efektów gospodarowania. Jak się wydaje za jedną z przyczyn takiego stanu rzeczy można uznać preferowanie w tych organizacjach systemu norm, wartości, sposobów postępowania a zatem kultury organizacyjnej ukierunkowanej głównie na realizację zadań przy braku lub ograniczonym nadawaniu określonych wartości człowiekowi, jego pracy, a w szczególności jego potrzebom i oczekiwaniom dotyczącym warunków jej świadczenia.

W tych okolicznościach nawet podejmowane próby podniesienia stanu bezpieczeństwa, zakładające dokonywanie zmian w technice, organizacji lub w technologii, bez modyfikacji kulturowych determinant działań, zazwyczaj nie doprowadzą do pożądanych rezultatów. Korzystny efekt tych zachowań staje się bowiem niweczony brakiem jego akceptacji z punktu widzenia przyjętego systemu wartości ${ }^{17}$.

Za szczególnie cenne należy zatem uznać ujawniony w trakcie przeprowadzonych badań przykład przedsiębiorstwa, w którym zarówno kierownictwo, jak i pracownicy dostrzegają potrzebę kreowania i akceptacji systemu wartości,

16 Z. Pawłowska, Kształtowanie kultury bezpieczeństwa..., op. cit., s. 122.

17 R. Studenski, Kultura bezpieczeństwa pracy..., op. cit., s. 4. 
norm, sposobów postępowania charakterystycznych dla „pożądanej” kultury bhp. Nie należy jednak zapominać, iż kształtowanie „pożądanej” kultury bhp, sprzyjającej nie tylko osiąganiu, ale przede wszystkim zachowaniu w dłuższym okresie czasu III i/lub IV poziomu bezpieczeństwa i higieny pracy, wymaga ciągłej dbałości o akceptację przyjętych cech kultury organizacyjnej.

Trzeba mieć świadomość, iż to ostatnie staje się coraz trudniejsze zarówno z uwagi na turbulentne, nie zawsze korzystne dla przedsiębiorstwa, zmiany w warunkach jego funkcjonowania, jak i z uwagi na zmiany w obrębie oczekiwań, interesów realizowanych w przedsiębiorstwie przez poszczególnych pracowników. Niezbędne staje się więc m.in. ciągłe monitorowanie przyjętych norm, wartości sposobów postępowania, a nade wszystko - z interesującego nas punktu widzenia - uświadamianie zatrudnionym i pracodawcom, iż kształtowanie cech kultury organizacyjnej w sposób sprzyjający doskonaleniu poziomu bhp pozostaje $\mathrm{w}$ bezpośredniej relacji z osiąganiem zamierzonych rezultatów szeroko rozumianego gospodarowania w przedsiębiorstwie.

\section{Bibliografia}

Armstrong M., Zarzqdzanie zasobami ludzkimi, Oficyna Ekonomiczna, Kraków 2005.

Cierniak-Emerych A., Warunki pracy - ich składowe oraz pożadane rezultaty ksztattowania w: Potencjat pracy przedsiębiorstwa, red. M. Gableta, Wyd. AE Wrocław, Wrocław 2006.

Gableta M., Karamalla E., Pojęcie i rola kultury organizacyjnej w przedsiębiorstwie, $\mathrm{w}$ : Potencjat pracy $w$ przedsiębiorstwie. Ksztattowanie $i$ wykorzystanie, red. M. Gableta, Wyd. AE Wrocław, Wrocław 1998.

Guldenmund F.W., (Mis)understanding Safety Culture and Its Relationship to Safety Management, "Risk Analysis" 2010, Vol. 30, no. 10.

Organizacja i zarzqdzanie, red. J. Boroń, AE Poznań, Poznań 1991.

Pawłowska Z., Kształtowanie kultury bezpieczeństwa i higieny pracy $w$ systemach zarzqdzania w: Nauka o pracy - bezpieczeństwo, higiena, ergonomia. Zarzqdzanie bezpieczeństwem i higiena pracy, Tom 8, red. D. Koradecka, Wyd. CIOP, Warszawa 2000.

Pocztowski A., Zarzadzanie zasobami ludzkimi. Zarys problematyki i metod, Wyd. Antykwa, Kraków 1998.

Podgórski D., Współczesne koncepcje zarzq̨zania bezpieczeństwem i higiena pracy w: Nauka o pracy - bezpieczeństwo, higiena, ergonomia. Zarzqdzanie bezpieczeństwem i higiena pracy, Tom 8, red. D. Koradecka, Wyd. CIOP, Warszawa 2000.

Rakowska A., Cichorzewska M., Rola przywództwa w ksztattowaniu kultury bezpieczeństwa pracy „Zeszyty Naukowe Wyższej Szkoły Bankowej we Wrocławiu” 2012, nr 30 . 
Studenski R., Kultura bezpieczeństwa pracy w przedsiębiorstwie, „Bezpieczeństwo Pracy" 2000, nr 9.

Weinstein M.B., Total Quality Safety Management and Auditing, Boca Raton FL, CRC Press LLC 1997.

Wspólnotowa strategia na rzecz podniesienia bezpieczeństwa $i$ higieny pracy, http://eur-lex.europa.eu/LexUriServ/LexUriServ.do?uri=OJ:C:2009:041E: 0014:0023:PL:PDF , [dostęp one-line 12.11.2012].

\section{Summary}

\section{Formation of Health and Safety Management in Companies vs. Characteristics of Organizational Culture}

The paper discusses the relationship between improvements in health and safety management and development of organizational culture, concerning health and safety culture as well. Attitudes and approaches to health and safety management are discussed in companies operating in the Lower Silesia region basing on the finding of empirical studies. Finally features of organizational culture identified in the companies under research are examined in the context of developing health and safety culture.

Keywords: organizational culture, health and safety culture, health and safety management, level of health and safety management, working conditions.

\section{Резюме}

\section{Формирование безопасности и гигены труда на предприятиях и свойства организационной культуры}

В работе объясняется связь между повышением уровня безопасности и гигены труда (охраны труда) на предприятии и формированием организационной культуры, в том числе культуры охраны труда. Ссылаясь на результаты эмпирических исследований, авторка охарактеризовала подход к вопросу безопасности и гигены труда на предприятиях, расположенных на территории Нижней Силезии. При этом особое внимание уделяет она выявленным свойствам организационной культуры, рассматривая их в контексте формирования культуры охраны труда. 
Ключевые слова: организационная культура, культура охраны труда, безопасность и гигена труда, уровень охраны труда, условия труда.

\section{Dr inż. Anna Cierniak-Emerych}

Doktor nauk ekonomicznych, inżynier, adiunkt w Katedrze Pracy i Stosunków Przemysłowych na Uniwersytecie Ekonomicznym we Wrocławiu. Jej zainteresowania naukowe pozostają w ramach nauki o przedsiębiorstwie, koncentrując się wokół problematyki funkcjonowania człowieka w przedsiębiorstwie i wykonywanej przez niego pracy. Największą aktywność naukową przejawia w obszarze kształtowania szeroko rozumianych warunków pracy w krajach Unii Europejskiej oraz zagadnienia partycypacji pracowniczej. Do jej zainteresowań naukowych należy również zagadnienie elastyczności, a zwłaszcza uelastyczniania sfery zatrudnienia. W 2012 r. otrzymała Nagrodę Indywidualną Rektora Uniwersytetu Ekonomicznego we Wrocławiu za osiągnięcia w dziedzinie pracy naukowo-badawczej. Jest autorką blisko 100 opracowań naukowych, w tym m.in. dwóch monografii, sześciu podręczników i skryptów. 
